\title{
DAMPAK IMPLEMENTASI TARIF O\% ACFTA TERHADAP NILAI EKSPOR 8 KOMODITAS PERTANIAN INDONESIA KE TIONGKOK
}

(The Impact Of The Implementation Of The Tariff Of 0\% Acfta (Asean China Free Trade Area) The Export Value Of Eight Agricultural Commodities Indonesia To China)

\author{
Ade Elvi Rahmah ${ }^{1}$, Akhmad Baihaqi ${ }^{1}$, Safrida $^{1^{*}}$ \\ ${ }^{1}$ Program Studi Agribisnis, Fakultas Pertanian, Universitas Syiah Kuala
}

\begin{abstract}
Abstrak - ASEAN China Free Trade Area (ACFTA) adalah suatu bentuk kerjasama perdagangan bebas antara negara Indonesia yang termasuk anggota ASEAN dengan negara Tiongkok. Kebijakan utama yang tertuang dalam kesepakatan tersebut yakni pembebasan dan penurunan tarif terhadap kegiatan perdagangan antara negara-negara yang tergabung didalamnya. Penelitian ini menganalisis apakah terdapat perbedan yang signifikan pada nilai ekspor komoditas pertanian Indonesia ke Tiongkok setelah adanya implementasi tarif $0 \%$ ACFTA dan bagaimana dampak dari implementasi kesepakatan perjanjian perdagangan bebas dalam ruang lingkup ACFTA (ASEAN China Free Trade Area) terhadap nilai ekspor 8 komoditas pertanian Indonesia ke Tiongkok yakni: (1) lemak dan minyak hewani/nabati, (2) karet dan produk karet, (3) kayu dan produk kayu, (4) ikan, udang, dan makanan laut lainnya, (5) kakao, (6) kopi, teh dan rempah, (7) sayuran dan buah-buahan, (8) gula dan kembang gula dengan menggunakan uji beda sampel berpasangan (Paired $\mathrm{T}$ Test) terhadap dua periode pengamatan, yakni sebelum dan sesudah ACFTA. Hasil analisis menunjukkan bahwa terdapat perbedaan yang signifikan ke arah peningkatan nilai ekspor setelah implementasi tarif $0 \%$ ACFTA serta implementasi tarif 0\% ACFTA berdampak positif bagi ekspor 8 komoditas pertanian indonesia ke Tiongkok. Adapun komoditas yang paling tinggi peningkatan nilai ekspor karena implementasi tarif 0\% ACFTA berturut-turut yakni minyak dan lemak hewani/nabati, karet dan produk karet serta kayu dan produk dari kayu.
\end{abstract}

Kata Kunci: ACFTA, Paired T Test, Komoditas Pertanian

Abstract - ASEAN China Free Trade Area (ACFTA) is a form of free trade agreements between ASEAN countries Indonesia as a member of the Chinese state. The main policy set out in the agreement the exemption and reduction in tariff on tarde between the countries incorporated in it. This study analyzes the impact of the implementation of the agreement of free trade agreements within the scope of the ACFTA (ASEAN China Free Trade Area) to the value of exports of 8 Indonesian agricultural commodities to China, namely: (1) fats and oils of animal / vegetable, (2) rubber and rubber products, (3) wood and wood products, (4) fish, shrimp and other seafood, (5) cocoa/chocolate, (6) coffee, tea, and spices, (7) of vegetables and fruits, (8) sugar and confectionery using different test paired samples (paired T test) against two observation periods, before and after the ACFTA. The empirical results show that the impact towards the increase in export value in eight commodity after the implementation of the ACFTA tariff of $0 \%$, but it is also supported by the correlation between the increase in value of exports and the implementation of ACFTA tariff of $0 \%$ strong and positive. These results support the hypothesis that the ACFTA positive impact on agricultural commodity 
exports 8 Indonesia to China. The commodity most of the increase in export values is due because the implementation of the tarrif of 0\% ACFTA is oil and animal fats/vegetable, rubber and rubber products, as well as wood and products of wood.

Keywords: ACFTA, Paired T Test, Agricultural Commodities

\section{PENDAHULUAN}

ASEAN China Free Trade Area adalah suatu bentuk kerjasama dibidang perdagangan antara negara-negara ASEAN yang termasuk Indonesia di dalamnya terhadap negara Tiongkok. Tujuan utama dari kesepakatan tersebut adalah menciptakan suatu kawasan yang dapat menunjang kegiatan ekspor negara-negara yang tergabung didalamnya, atau dengan kata lain terciptanya suatu kawasan perdagangan bebas. Erawaty (2003), mengemukakan pembentukan kawasan perdagangan bebas dapat merujuk pada kondisi dimana pertukaran barang dan jasa antar negara berlangsung tanpa adanya hambatan ekspor-impor dan jikalaupun itu ada maka jumlah, jenis dan tingkatannya haruslah seminimal mungkin.

Gagasan pembentukan ACFTA pertama kalinya disepakati dalam konferensi Tingkat Tinggi (KTT) ASEAN ke-7 di Bandar Sri Begawan, Brunei Darussalam, pada 6 November 2001. Kemudian disusul dengan pengesahan melalui penandatanganan Kerangka Kerja mengenai "Kerjasama Ekonomi Menyeluruh antara Negara-negara Anggota ASEAN dan Republik Rakyat Tiongkok" di Phnom Penh, Kamboja, pada tanggal 4 November 2002 namun belum efektif pada saat itu. Kawasan perdagangan bebas ASEAN- Tiongkok secara resmi diberlakukan pada 1 Januari 2010. Yakni di berlakukannya bea masuk 0\% antara Tiongkok dengan ASEAN-6 yakni Indonesia, Singapura, Malaysia, Brunei, Philipina dan Thailand. Sedangkan untuk negara-negara anggota baru ASEAN seperti Laos, Myanmar, Vietnam, dan Kamboja mulai di berlakukan pada tahun 2015 (Direktorat Jendral Kerjasama Perdagangan Internasional, 2011).

Tiongkok sebagai negara dengan jumlah penduduk terbesar didunia yakni 1.9 milyar jiwa, menjadikannya sebagai pasar yang cukup potensional bagi Indonesia dalam memasarkan. Cashmore (2003) menjelaskan bahwa Tiongkok merupakan negara yang akan memimpin produksi di kawasan Asia bersama dengan India, namun di sisi lain negara-negara tersebut tidak kaya akan sumber daya alam, sehingga tanpa adanya bantuan dari negara lain akan menghambat proses produksinya. Indonesia merupakan negara penghasil komoditas dan kaya akan sumber daya alam dengan letak geografis yang cukup dekat dengan Tiongkok. Indonesia sudah seharusnya memanfaatkan peluang tersebut dengan mengekspor berbagai sumber daya/komoditas untuk memenuhi permintaan dari Tiongkok.

Berbagai sektor komoditas turut menyumbang pendapatan Indonesia melalui kegiatan ekspor Indonesia ke Tiongkok. Salah satu sektor yang cukup berperan adalah sektor pertanian. Berikut ini adalah nilai ekspor 8 jenis komoditas pertanian Indonesia ke Tiongkok dalam beberapa tahun terakhir selama implementasi ACFTA.

Tabel 1 memperlihatkan 8 jenis komoditas dari keseluruhan jenis yang diekspor Indonesia ke Tiongkok dalam kurun beberapa tahun terakhir selama ACFTA dilaksanakan. Berbagai komoditas tersebut mewakili komoditas ekspor di sektor pertanian dan perikanan, yang memegang peranan penting dalam kinerja ekspor nasional ke negara Tiongkok. 
Berdasarkan kriteria Kementerian Perdagangan Republik Indonesia, 8 jenis komoditas pertanian ini menjadi penyumbang pendapatan negara dari kegiatan perdagangan luar negeri Indonesia ke Tiongkok, serta berperan penting dalam mensejahterakan para pelaku pada tiap tingkatan kegiatan produksi komoditas tersebut (Kementrian Perdagangan Republik Indonesia, 2010).

Tabel 1. Jenis Komoditas Pertanian Beserta Nilai Ekspor Indonesia ke Tiongkok

\begin{tabular}{|c|c|c|c|c|c|c|c|c|c|c|}
\hline \multirow[t]{2}{*}{ Komoditas } & \multicolumn{10}{|c|}{ Nilai Ekspor Indonesia ke China (Juta US Dollar) } \\
\hline & 2005 & 2006 & 2007 & 2008 & 2009 & 2010 & 2011 & 2012 & 2013 & 2014 \\
\hline $\begin{array}{l}\text { Minyak hewani dan } \\
\text { Nabati }\end{array}$ & 341 & 689,4 & 762,1 & 901,2 & 838,9 & 1016 & 1606 & 2135 & 2782 & 2381 \\
\hline $\begin{array}{l}\text { Karet dan Produk } \\
\text { Karet }\end{array}$ & 341 & 689,4 & 762,1 & 901,2 & 838,9 & 961 & 1706 & 2235 & 2682 & 2381 \\
\hline $\begin{array}{l}\text { Kayu dan Produk } \\
\text { Kayu }\end{array}$ & 209,1 & 224 & 194,7 & 174,4 & 227,9 & $\begin{array}{c}554 \\
6\end{array}$ & 600,2 & 400,1 & 390,3 & 658 \\
\hline $\begin{array}{l}\text { Ikan, Udang, dan } \\
\text { Makanan Laut } \\
\text { Lainnya }\end{array}$ & 35,8 & 40,4 & 23,5 & 66,0 & 54,3 & $\begin{array}{c}123 \\
7\end{array}$ & 168,8 & 119,9 & 256,2 & 221,4 \\
\hline Kakao/Cokelat & 22,7 & 25,7 & 37,4 & 40,4 & 25,9 & 61,8 & 81,4 & 68,3 & 110,5 & 93,2 \\
\hline $\begin{array}{l}\text { Kopi, teh dan } \\
\text { rempah }\end{array}$ & 3,7 & 3,0 & 3,2 & 4,7 & 4,1 & 27,2 & 14,5 & 23,8 & 50,8 & 41,2 \\
\hline $\begin{array}{l}\text { Sayuran dan Buah- } \\
\text { buahan }\end{array}$ & 15,1 & 16,6 & 20,9 & 22,7 & 23,6 & 24,0 & 26,8 & 28 & 31,6 & 32,9 \\
\hline $\begin{array}{l}\text { Gula dan kembang } \\
\text { gula }\end{array}$ & 0,6 & 1,1 & 0,9 & 1,8 & 1,5 & 2,2 & 3,8 & 2,7 & 6,6 & 5,5 \\
\hline
\end{tabular}

Ket: Harga yang digunakan adalah harga yang berlaku saat itu

Sumber: International Trade Centre Statistics, 2016

Keikutsertaan Indonesia di dalam kerjasama perdagangan bebas dengan Tiongkok diharapakan membawa dampak positif bagi kemajuan sektor perdagangan internasioanl Indonesia dalam hal ekspor. Serta memberikan peluang yang cukup terbuka bagi kegiatan ekspor komoditas pertanian yang selama ini dihasilkan dan sekaligus menjadi tantangan untuk menghasilkan komoditas yang kompetitif di pasar regional ACFTA.

Dari uraian latar belakang di atas penulis tertarik melakukan penelitian mengenai dampak implementasi tarif 0\% ACFTA (ASEAN-China Free Trade Area) terhadap nilai ekspor 8 komoditas pertanian Indonesia ke Tiongkok 
Adapun tujuan dari penelitian ini adalah untuk mengetahui dampak implementasi tarif 0\% ACFTA terhadap nilai ekspor 8 komoditas pertanian Indonesia ke Tiongkok dilihat pada saat sebelum dan sesudah di berlakukannya ACFTA

\section{METODE PENELITIAN}

Fokus lokasi dalam penelitian ini yakni mengenai hubungan perdagangan bebas antara negara Indonesia yang tergabung sebagai anggota ASEAN terhadap negara Tiongkok. Objek dalam penelitian ini adalah nilai ekspor 8 komoditas pertanian (minyak hewani/nabati; kakao/coklat; karet dan produk karet; ikan, udang, dan makanan laut lainnya; kopi, teh dan rempah; kayu dan produk kayu; sayuran dan buah-buahan; gula dan kembang gula) Indonesia ke Tiongkok. Ruang lingkup penelitian ini adalah mencakup pada perubahan nilai ekspor komoditas pertanian Indonesia ke Tiongkok pada saat sebelum dan sesudah diimplementsikan tarif 0\% ACFTA dan dampak ACFTA terhadap komoditas pertanian Indonesia akibat adanya implementasi tarif 0\% ACFTA.

\section{Teknik Pengumpulan Data}

Penelitian ini menggunakan data runtun waktu (time series) selama 10 tahun berturutturut pada 8 komoditas pertanian yang diekspor Indonesia ke Tiongkok. . Periode sebelum diambil lima tahun pada saat sebelum implentasi tarif 0\% ACFTA yaitu tahun 2005-2009, kemudian dibandingkan dengan lima tahun setelah implentasi tarif 0\% ACFTA yang dilaksanakan tahun 2010-2014 pada tiap tiap komoditas di dalam penelitian.

Data bersifat kuantitatif dalam bentuk tahunan (annual), dari tahun sebelum implementasi tarif 0\% ACFTA pada tahun 2005-2009 dan periode dimana tarif 0\% ACFTA mulai efektif diberlakukan pada tahun 2010-2014. Data yang digunakan dalam penelitian ini adalah data 8 komoditas pertanian ekspor Indonesia ke Tiongkok.

Sumber data yang digunakan dalam penelitian ini adalah data sekunder yang diperoleh dari berbagai sumber seperti situs resmi International Trade Centre, World of Bank, UNCOMTRADE dan hasil laporan-laporan dari suatu penelitian. Disamping itu data lainnya yang mendukung penelitian ini diperoleh dari sumber bacaan seperti, buletin penelitian, jurnal ilmiah, dan buku bacaan.

\section{Teknik Analisis Data}

Uji Normalitas

Uji normalitas dilakukan untuk mengetahui apakah data yang terdapat didalam penelitian berdistriusi normal atau tidak. Jika data berdistribusi normal berarti teknik analisis yang digunakan adalah statistik parametrik, sedangkan jika tidak berdistribusi normal maka teknik analisis data yang akan digunakan adalah statistik non parametrik (Ghozali, 2009).

Dengan pedoman sebagai berikut:

a. Jika angka signifikansi (SIG) $>0,05$, maka distribusi data normal

b. Jika angka signifikansi (SIG) $<0,05$, maka distribusi data tidak normal

\section{Uji Beda T Sampel Berpasangan (Paired T Test)}

Analisis ini digunakan untuk menguji apakah terdapat perbedaan rata-rata dua sampel yang berhubungan (Ghozali, 2009). Sampel yang berhubungan tersebut yaitu 8 komoditas pertanian ekspor Indonesia ke Tiongkok sebelum dan sesudah implementasi tarif 0\% ACFTA 
dilaksanakan. Periode sebelum diambil 5 tahun pada saat sebelum ACFTA dilaksanakan yaitu 2005-2009, kemudian dibandingkan dengan 5 tahun setelah ACFTA dilaksanakan tahun 2010-2014 pada tiap tiap komoditas di dalam penelitian.

Dasar pengambilan keputusan:

(1) jika probabilitas $>0,05$, maka terima Ho tolak Ha, artinya tidak terdapat perbedaan yang signifikan

(2) jika probabilitasnya $<0,05$ maka tolak Ho terima Ha, artinya terdapat perbedaan yang signifikan dan nyata.

Dimana:

Ho = Tidak terdapat perbedaan yang signifikan pada nilai ekspor komoditas pertanian Indonesia ke Tiongkok setelah adanya implementasi tarif 0\% ACFTA

$\mathrm{Ha}=$ Terdapat perbedaan yang signifikan pada nilai ekspor komoditas pertanian Indonesia ke Tiongkok setelah adanya implementasi tarif 0\% ACFTA.

Berdasarkan perbandingan t hitung dan t tabel

(1) Jika t hitung $>$ t tabel, maka tolak Ho

(2) Jika t hitung < t tabel, maka terima Ho

Santoso (2000) menjelaskan perhitungan $t$ hitung untuk penggunaan sampel berpasangan sebagai berikut:

$$
\text { thitung }=\frac{\bar{X}_{1}-\bar{X}_{2}}{\sqrt{\left[\frac{\left(n_{1}-1\right) S_{1^{2}}+\left(n_{2}-1\right) S_{2}}{n_{1}+n_{2}-2}\right]\left[\frac{1}{n_{1}}+\frac{1}{n_{2}}\right]}}
$$

Keterangan:

$X_{1}=$ rata-rata variabel 1 (sebelum ACFTA)

$X_{2}=$ rata-rata variabel 2 (sesudah ACFTA)

$\mathrm{S}_{1}=$ simpangan baku variabel 1

$\mathrm{S}_{2}=$ simpangan baku variabel 2

$\mathrm{n}_{1}=$ jumlah sampel variabel 1

$\mathrm{n}_{2}=$ jumlah sampel variabel 2

\section{HASIL DAN PEMBAHASAN}

Grafik diatas dapat dilihat pada 2010 yakni tahun dimana mulai diimplementasikannya tarif 0\% ACFTA nilai ekspor minyak dan lemak hewani/nabati Indonesia ke Tiongkok mencapai US\$ 1016 juta, setelah sebelumnya pada tahun 2009 mencapai US\$ 838,9 juta pasca Tiongkok terlibat di dalam AFTA. Dampak positif ini sangat terlihat setelah tarif 0\% ACFTA diimplementasikan pada tahun 2010 dan terus berlanjut hingga tahun-tahun berikutnya. 
Grafik 1. Perkembangan Ekspor Lemak dan Minyak Hewani/Nabati ke Tiongkok

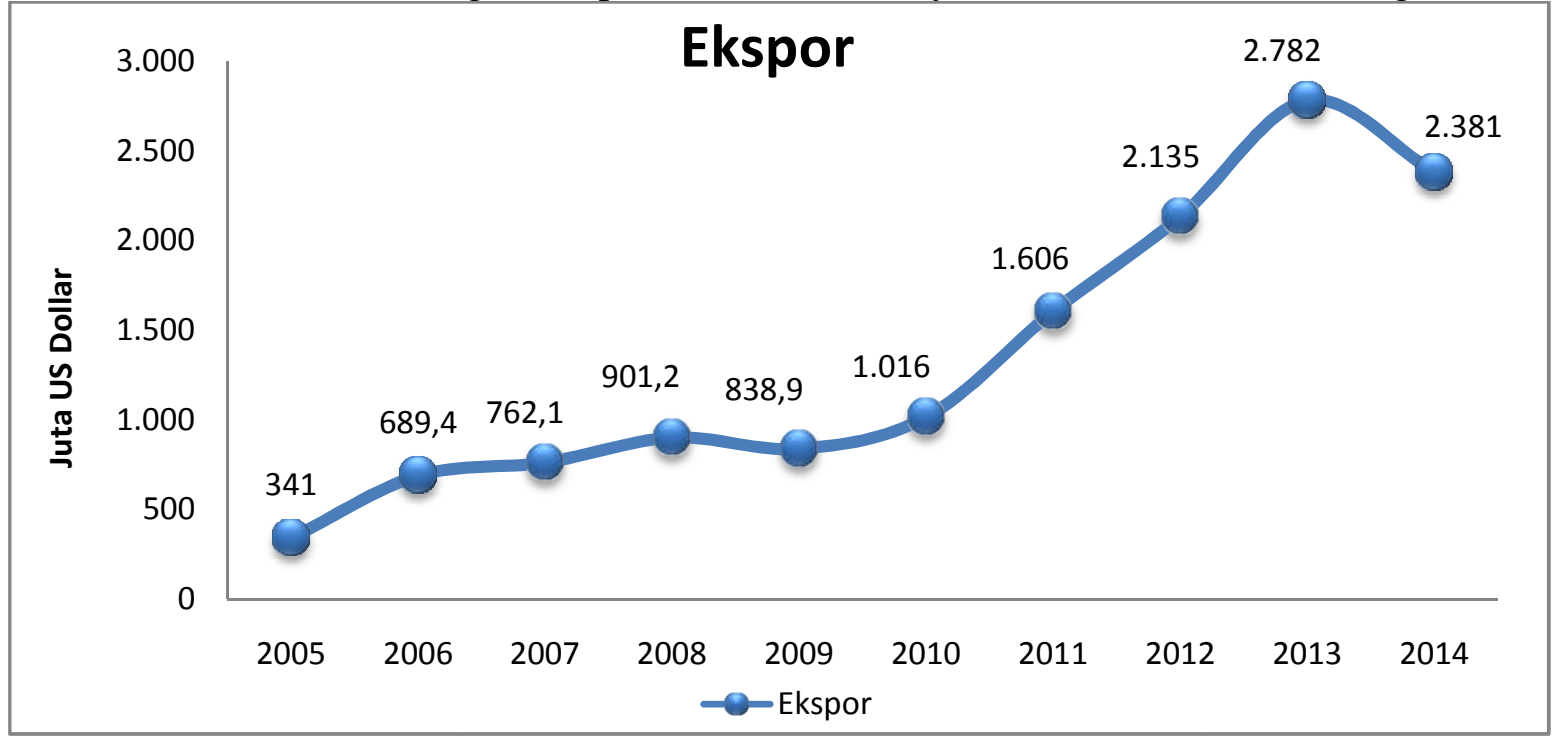

Sumber: International Trade Centre Statistics, 2016 (diolah), harga yang digunakan berlaku saat itu

Grafik 2. Perkembangan Ekspor Karet dan Produk Karet Indonesia ke Tiongkok

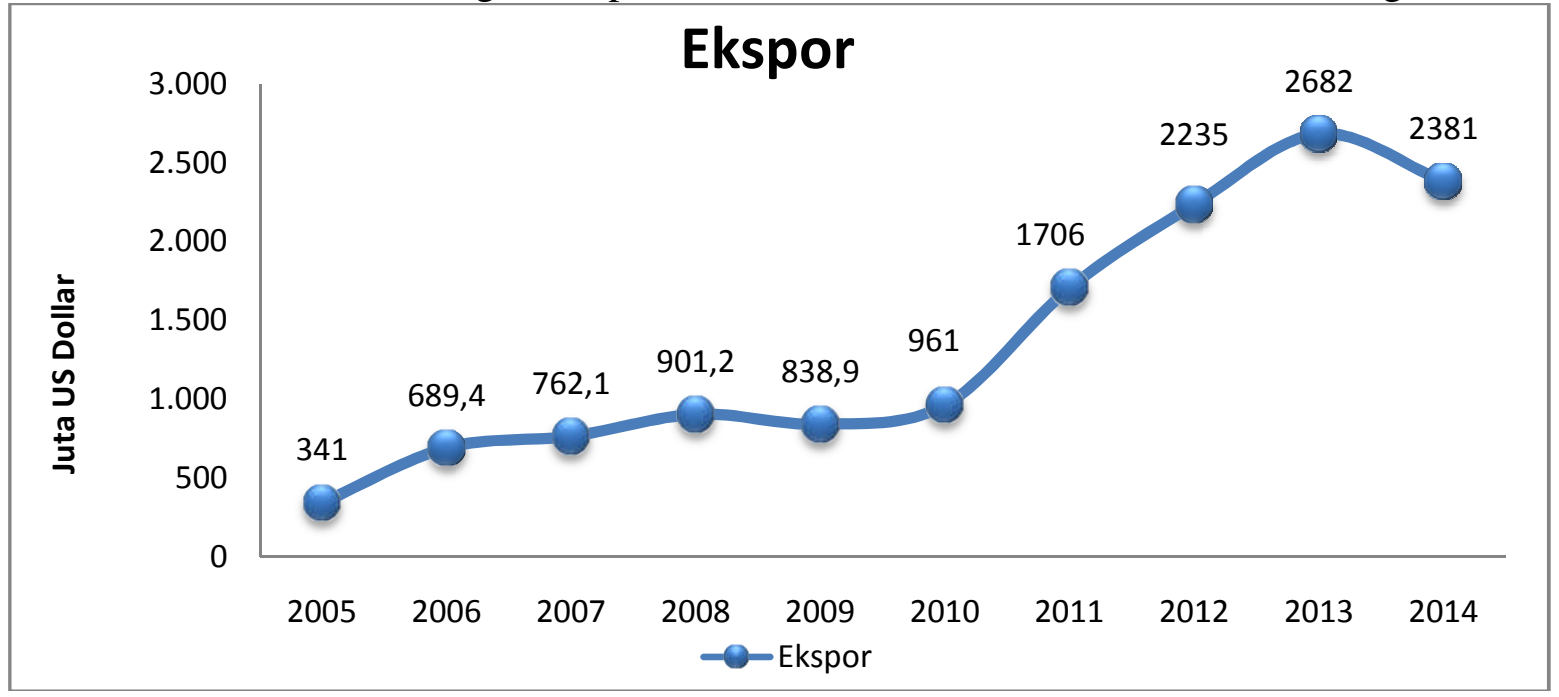

Sumber: International Trade Centre Statistics, 2016 (diolah), harga yang digunakan adalah harga berlaku

Memasuki tahun 2010 disaat tarif 0\% ACFTA diimplementasikan secara aktif, nilai ekspor karet dan produk karet meningkat secara drastis. Hal ini sesuai dengan harapan dan ekspektasi pemerintah bahwa ACFTA berdampak positif terhadap nilai ekspor komoditas ini. Peningkatan pada tahun awal implementasi ACFTA pada tahun 2010 mencapai titik US\$ 961 juta bergerak dari titik US\$ 838,9 juta pada tahun sebelumnya yakni 2009. Peningkatan ini 
terus berlanjut pada tahun-tahun berikutnya. Pada tahun 2011 hingga 2013 terus mengalami peningkatan yakni mencapai US\$ 2682 juta. Namun terjadi penurunan di tahun 2014 yakni US\$ 2381 juta, kendati demikian penurunan ini tidak kurang dari pencapaian pada tahun 2010.

Grafik 3. Perkembangan Ekspor Kayu dan Produk Kayu Indonesia ke Tiongkok

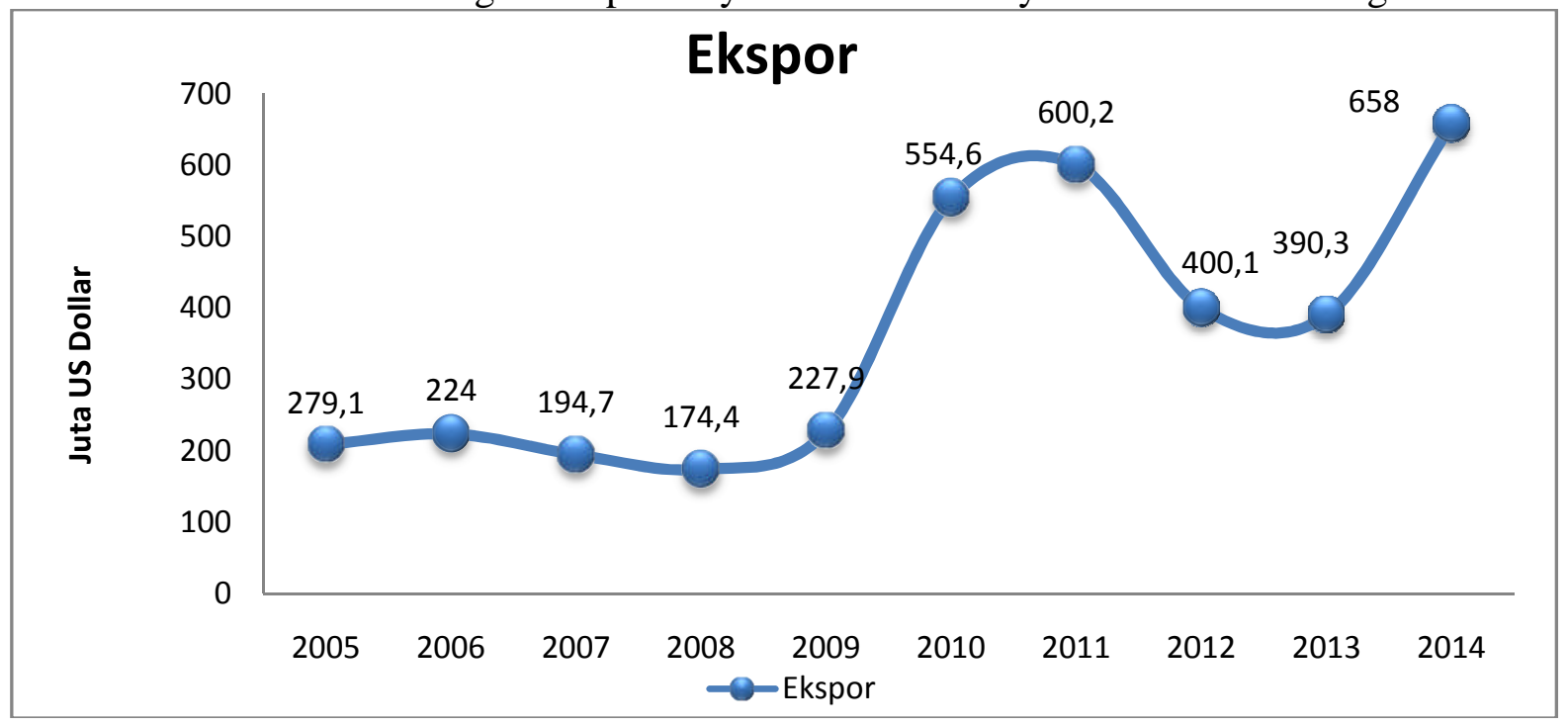

Sumber: International Trade Centre Statistics, 2016 (diolah), harga yang digunakan adalah harga berlaku

Pada tahun 2010 disaat tarif 0\% ACFTA diimplementasikan secara aktif membawa dampak yang cukup baik bagi eksistensi ekspor kayu dan produk dari kayu Indonesia ke Tiongkok. Kondisi ekspor yang memburuk pada tahun-tahun sebelumnya kini membaik, nilai ekspor komoditas ini bergerak naik mencapai US\$ 554,6 juta, kondisi seperti ini tentunya membawa angin segar bagi industri kayu dan produk kayu yang sempat terpuruk pada periode-periode sebelum diimplementasikan ACFTA. Pada tahun-tahun selanjutnya nilai ekspor kayu dan produk dari kayu terus bergerak naik, hingga pencapaian tertinggi terjadi pada tahun 2014 mencapai US\$ 658 juta.

Pada grafik di atas dapat dilihat disaat implementasinya pada tahun 2010 membawa kabar baik bagi produsen dalam negeri yang menghasilkan komoditas ini. Nilai ekspor ikan udang, dan makanan laut lainnya Indonesia ke Tiongkok naik ke titik US\$ 123,7 juta, hal ini merupakan pencapaian yang belum pernah terjadi sebelumnya. Seakan implementasi ACFTA membawa Indonesia ke era ekspor yang lebih tinggi dari sebelumnya. Tidak berhenti pada pencapaian yang baik pada tahun 2010, peningkatan yang sangat drastis terjadi pada tahuntahun selanjutnya. Yakni pada tahun 2011 hingga 2014 kenaikan nilai ekspor mencapai US\$ 221,4 juta. 
Grafik 4. Perkembangan Ekspor Ikan, Udang, dan Makanan Laut Lainnya

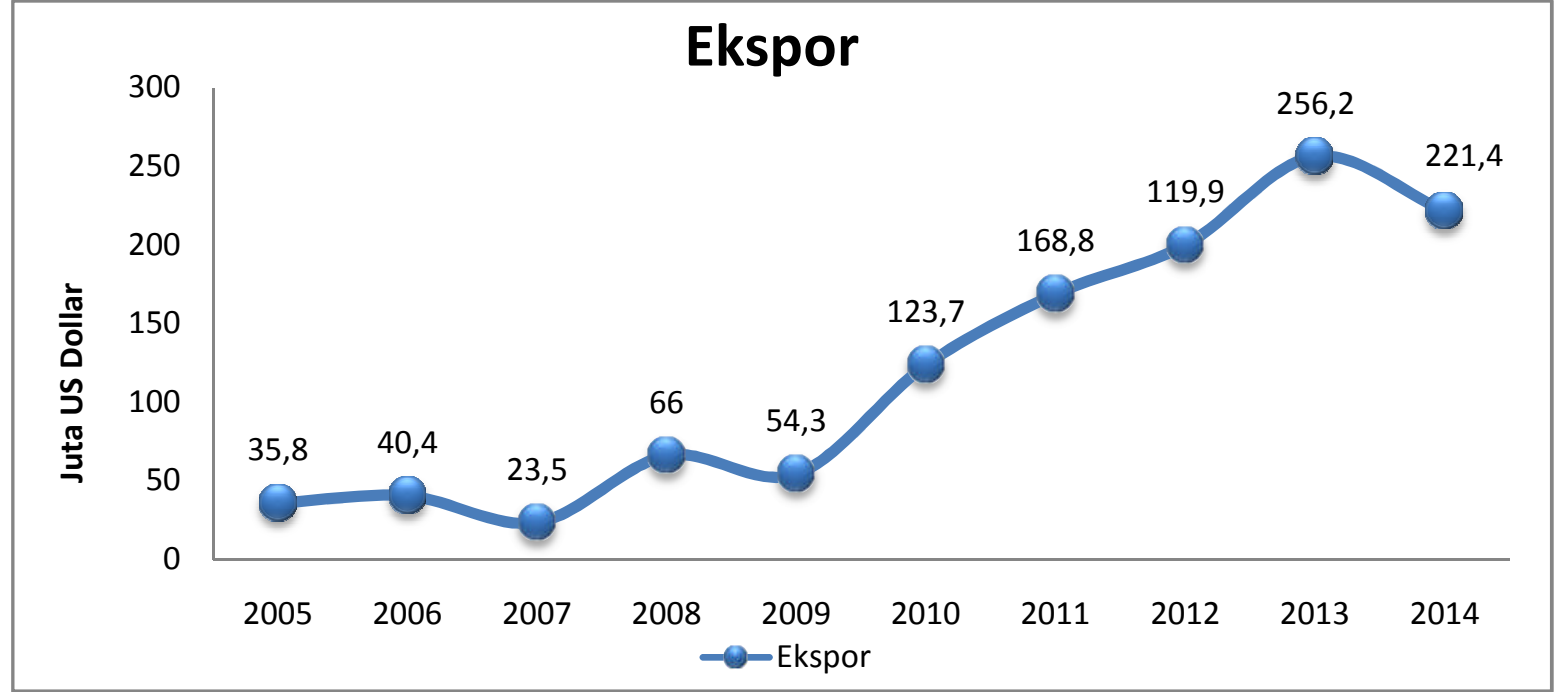

Sumber: International Trade Centre Statistics, 2016 (diolah), harga yang digunakan adalah harga berlaku

Grafik 5. Perkembangan Ekspor Kakao/Coklat Indonesia ke Tiongkok

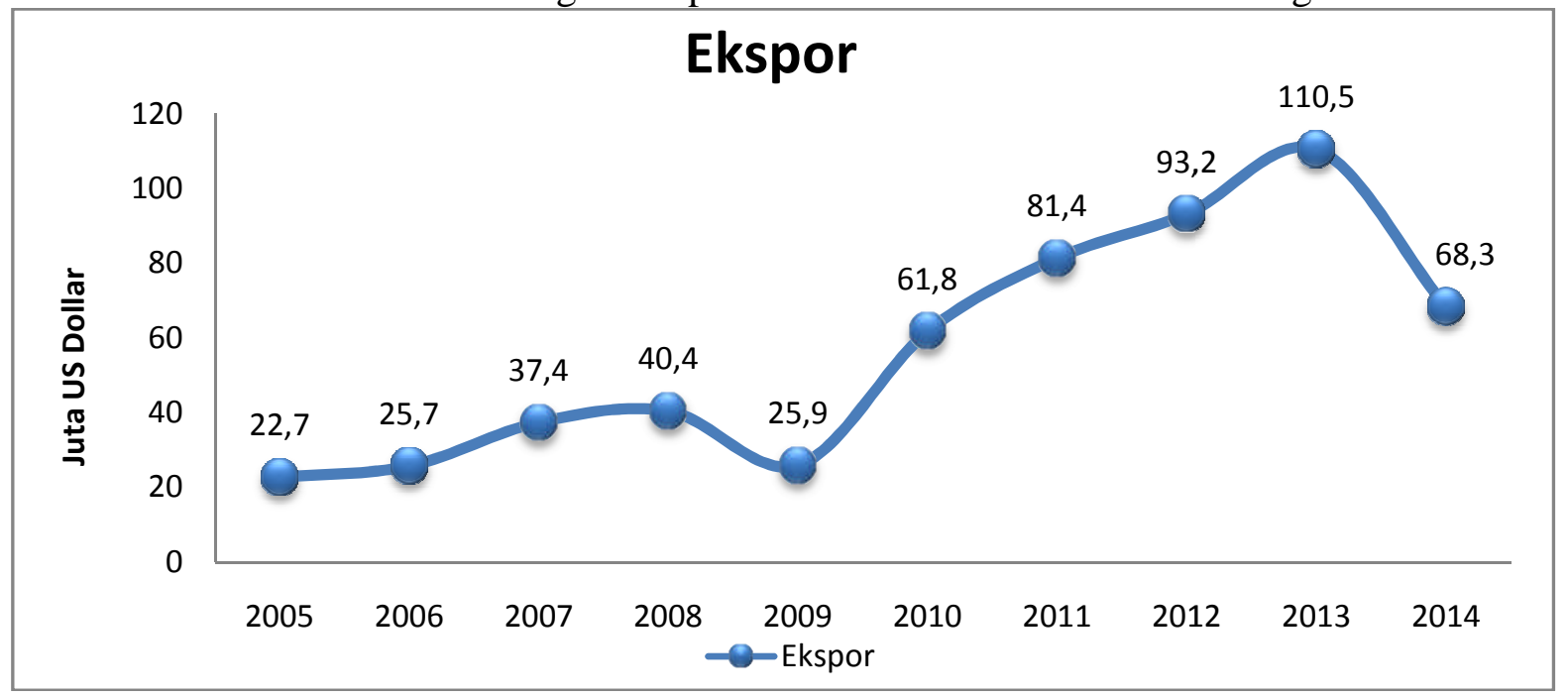

Sumber: International Trade Centre Statistics, 2016 (diolah), harga yang digunakan adalah harga berlaku

Kebangkitan ekspor kakao ke Tiongkok dimulai pada tahun 2010, bertepatan dengan aktifnya implementasi tarif 0\% ACFTA secara menyeluruh. Seakan membawa nilai ekspor kakao Indonesia ke Tiongkok menuju level yang baru dibandingkan periode sebelumnya. Peningkatan nilai ekspor kakao pada tahun 2010 mencapai US\$ 61,8 juta dan terus meningkat hingga tahun 2013 yakni sebesar US\$ 110,5 juta namun pada tahun 2014 mengalami 
penurunan yakni sebesar US\$ 68,3 juta. Kendati demikian penurunan ini tidak lebih rendah dibandingkan pencapaian pada tahun 2010.

Grafik 6. Perkembangan Ekspor Kopi, Teh dan Rempah Indonesia ke Tiongkok

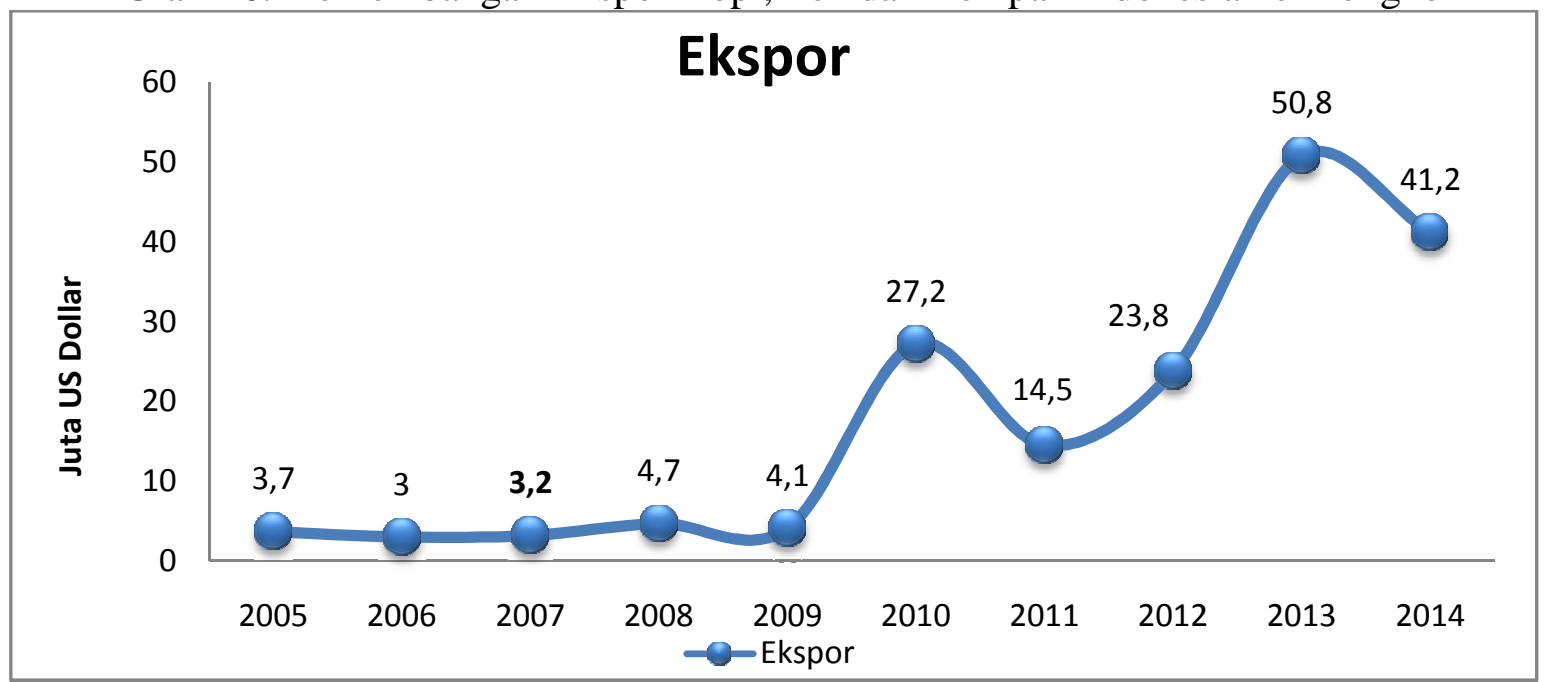

Sumber: International Trade Centre Statistics, 2016 (diolah), harga yang digunakan adalah harga berlaku

Memasuki tahun 2010 disaat tarif 0\% ACFTA diimplementasikan secara aktif, nilai ekspor kopi, teh dan rempah meningkat secara drastis. Peningkatan pada tahun awal implementasi ACFTA pada tahun 2010 mencapai titik US\$27,2 juta bergerak dari titik US\$ 4,1 juta pada tahun sebelumnya yakni 2009. Peningkatan ini terus berlanjut pada tahun-tahun berikutnya, namun sempat mengalami penurunan pada tahun 2011 yakni sebesar US\$14,5 juta. Pada tahun 2012 meningkat ke titik US\$ 23,8 juta, dan kemudian mengalami peningkatan yang cukup drastis yakni mencapain US\$ 50,8 juta. Turun kembali pada tahun 2014 ke titik US\$ 41,2 juta.

Grafik 7. Perkembangan Ekspor Sayuran dan Buah-buahan Indonesia ke Tiongkok

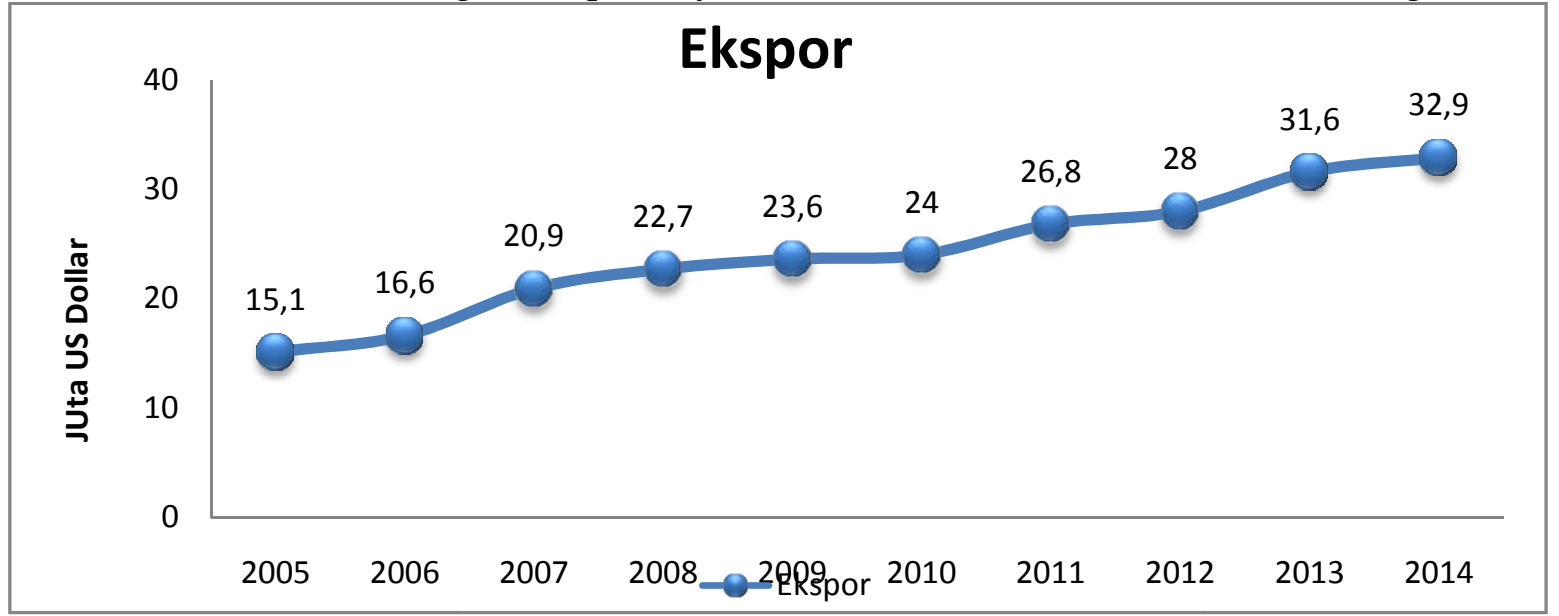

Sumber: International Trade Centre Statistics, 2016 (diolah), harga yang digunakan adalah harga berlaku 
Dimulai pada tahun 2010, bertepatan dengan aktifnya implementasi tarif 0\% ACFTA secara menyeluruh ekspor komoditas sayuran dan buah-buahan Indonesia ke Tiongkok semakin meperlihatkan kemajuan yang positif. Hal ini terlihat pada tahun 2010 nilai ekspor komoditas ini meningkat menjadi US\$ 24 juta dan terus meningkat hingga tahun 2014 mencapai titik US\$32,9 juta.

Grafik 8. Perkembangan Ekspor Gula dan Kembang Gula Indonesia ke Tiongkok

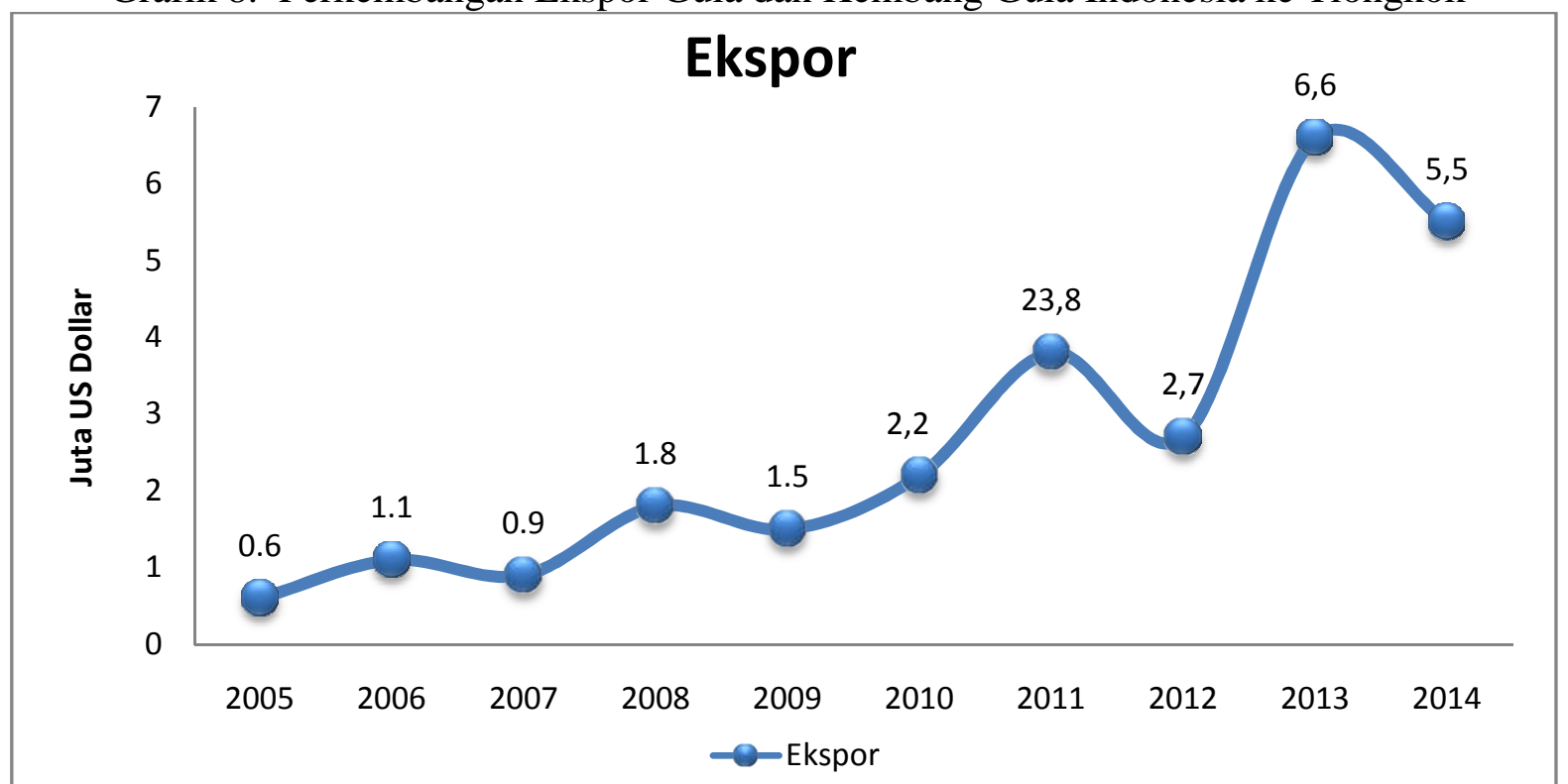

Sumber: International Trade Centre Statistics, 2016 (diolah), harga yang digunakan adalah harga berlaku

Pada tahun 2010 disaat tarif 0\% ACFTA diimplementasikan secara aktif membawa dampak yang cukup baik bagi eksistensi ekspor gula dan kembang gula (confectionary) Indonesia ke Tiongkok. Ekspor komoditas ini kembali naik ke titik US\$1,8 juta pada awal tahun 2010 dan terus mengalami kenaikan pada tahun 2011 hingga 2012 mencapai titik US\$ 4,8 juta hingga US\$ 6,6 juta. Kemudian pada tahun 2013 dan 2014 mengalami penurunan drastis yakni dari US\$ 5,1 juta turun ke titik US\$ 2,5 juta. Kendati demikian, penurunan nilai ekspor tersebut tidak kurang dari pencapaian di tahun 2010.

\section{Analisis dan Pengujian Hipotesis}

Tabel 2 memperlihatkan hasil uji normalitas dari 8 komoditas pertanian yang diekspor ke Tiongkok, diuji berdasarkan periode lima tahun sebelum dan lima tahun sesudah tarif $0 \%$ ACFTA diimplementasikan. Terlihat bahwa keseluruhan data berdistribusi normal.

Tabel 2. Hasil Uji Normalitas Kolmogrov Smirnov Test

Dampak Implementasi tarif 0\% ACFTA terhadap Nilai Ekspor 8 Komoditas Pertanian Indonesia 


\begin{tabular}{|c|c|c|c|c|}
\hline Komoditas & Periode & $\mathrm{N}$ & $\begin{array}{l}\text { Kolmogrov } \\
\text { Smirnov-Z }\end{array}$ & $\begin{array}{c}\text { Asymp } \\
\text { Signifikan (2 } \\
\text { Tailed) }\end{array}$ \\
\hline \multirow{2}{*}{$\begin{array}{l}\text { Lemak dan Minyak } \\
\text { Hewani/Nabati }\end{array}$} & Sebelum & 5 & 0,60 & 0,86 \\
\hline & Sesudah & 5 & 0.41 & 0,99 \\
\hline \multirow{2}{*}{$\begin{array}{l}\text { Karet dan Produk dari } \\
\text { Karet }\end{array}$} & Sebelum & 5 & 0,60 & 0,86 \\
\hline & Sesudah & 5 & 0,53 & 0,93 \\
\hline \multirow[t]{2}{*}{ Kayu dan Produk Kayu } & Sebelum & 5 & 0,43 & 0,99 \\
\hline & Sesudah & 5 & 0,54 & 0,93 \\
\hline \multirow{2}{*}{$\begin{array}{l}\text { Ikan, Udang dan } \\
\text { Makanan Laut lainnya }\end{array}$} & Sebelum & 5 & 0,41 & 0,99 \\
\hline & Sesudah & 5 & 0,48 & 0,97 \\
\hline \multirow[t]{2}{*}{ Kakao/Coklat } & Sebelum & 5 & 0,70 & 0,70 \\
\hline & Sesudah & 5 & 0,65 & 0,77 \\
\hline \multirow[t]{2}{*}{ Kopi, Teh dan Rempah } & Sebelum & 5 & 0,41 & 0,99 \\
\hline & Sesudah & 5 & 0,50 & 0,96 \\
\hline \multirow{2}{*}{$\begin{array}{l}\text { Sayuran dan Buah- } \\
\text { Buahan }\end{array}$} & Sebelum & 5 & 0,48 & 0,97 \\
\hline & Sesudah & 5 & 0,42 & 0,99 \\
\hline \multirow[t]{2}{*}{ Gula dan Kembang Gula } & Sebelum & 5 & 0,37 & 0,99 \\
\hline & Sesudah & 5 & 0,50 & 0,95 \\
\hline
\end{tabular}

Sumber: Hasil uji normalitas, diolah menggunakan program SPSS 19, (2016)

Tabel 3. Hasil Uji Statistik Sampel Berpasangan 


\begin{tabular}{|c|c|c|c|c|c|}
\hline Komoditas & Periode & $\mathrm{N}$ & Mean & $\begin{array}{l}\text { Standar } \\
\text { Deviasi }\end{array}$ & $\begin{array}{c}\text { Standar } \\
\text { ErorMean }\end{array}$ \\
\hline \multirow{2}{*}{$\begin{array}{l}\text { Lemak dan Minyak } \\
\text { Hewani/Nabati }\end{array}$} & Sebelum & 5 & 1050 & 942,05 & 421,29 \\
\hline & Sesudah & 5 & 2922 & 1984,16 & 887,34 \\
\hline \multirow{2}{*}{$\begin{array}{l}\text { Karet dan Produk dari } \\
\text { Karet }\end{array}$} & Sebelum & 5 & 706,52 & 219,32 & 98,08 \\
\hline & Sesudah & 5 & 1984 & 649,94 & 290,66 \\
\hline \multirow[t]{2}{*}{ Kayu dan Produk kayu } & Sebelum & 5 & 205,96 & 58,99 & 26,38 \\
\hline & Sesudah & 5 & 520,64 & 196,43 & 87,84 \\
\hline \multirow{2}{*}{$\begin{array}{l}\text { Ikan, Udang dan Makanan } \\
\text { Laut lainnya }\end{array}$} & Sebelum & 5 & 44 & 16,51 & 7,38 \\
\hline & Sesudah & 5 & 178 & 68,38 & 30,58 \\
\hline \multirow[t]{2}{*}{ Kakao/Coklat } & Sebelum & 5 & 30,42 & 7,91 & 3,54 \\
\hline & Sesudah & 5 & 83,04 & 19,54 & 8,74 \\
\hline \multirow[t]{2}{*}{ Kopi, Teh dan Rempah } & Sebelum & 5 & 3,74 & 0,68 & 0,30 \\
\hline & Sesudah & 5 & 31,50 & 14,43 & 6,45 \\
\hline \multirow[t]{2}{*}{ Sayuran dan Buah-Buahan } & Sebelum & 5 & 19,78 & 4,86 & 2,17 \\
\hline & Sesudah & 5 & 28,46 & 6,62 & 2,96 \\
\hline \multirow[t]{2}{*}{ Gula dan Kembang Gula } & Sebelum & 5 & 1,18 & 0,47 & 0,21 \\
\hline & Sesudah & 5 & 4,16 & 1,86 & 0,83 \\
\hline
\end{tabular}

Sumber: Hasil uji statistik sampel berpasangan, diolah menggunakan program SPSS 19, (2016)

Tabel 3 merupakan hasil uji statistik yang memperlihatkan nilai mean, standar deviasi dan standar eror mean pada masing-masing komoditas periode sebelum dan sesudah implementasi tarif 0\% ACFTA. 
Dari Tabel 3 diatas dapat di jelaskan bahwa hasil uji statistik untuk keseluruhan jenis komoditas pertanian memperlihatkan nilai mean pada periode sesudah implementasi tarif $0 \%$ ACFTA lebih tinggi dibandingkan periode sebelum implementasi tarif 0\% ACFTA. Dengan kata lain terjadinya perubahan (peningkatan) nilai ekspor setelah adanya implementai tarif $0 \%$ ACFTA tersebut.

Tabel 4. Hasil Uji Korelasi Sampel Berpasangan

\begin{tabular}{|l|c|c|c|c|}
\hline \multicolumn{1}{|c|}{ Komoditas } & $\mathrm{n}$ & \multicolumn{1}{c|}{ Periode } & Korelasi & $\begin{array}{c}\text { Signifikan } \\
\text { Korelasi }\end{array}$ \\
\hline $\begin{array}{l}\text { Lemak dan Minyak } \\
\text { Hewani/Nabati }\end{array}$ & 5 & Sebelum-Sesudah & 0.954 & 0.012 \\
\hline $\begin{array}{l}\text { Karet dan Produk dari } \\
\text { Karet }\end{array}$ & 5 & Sebelum-Sesudah & 0.982 & 0.003 \\
\hline Kayu dan Produk Kayu & 5 & Sebelum-Sesudah & 0.946 & 0.015 \\
\hline $\begin{array}{l}\text { Ikan, Udang dan Makanan } \\
\text { Laut lainnya }\end{array}$ & 5 & Sebelum-Sesudah & 0.968 & 0.007 \\
\hline Kakao/Coklat & 5 & Sebelum-Sesudah & 0.942 & 0.016 \\
\hline Kopi, Teh dan Rempah & 5 & Sebelum-Sesudah & 0.980 & 0.003 \\
\hline Sayuran dan Buah-Buahan & 5 & Sebelum-Sesudah & 0.954 & 0.012 \\
\hline Gula dan Kembang Gula & 5 & Sebelum-Sesudah & 0.991 & 0.001 \\
\hline
\end{tabular}

Sumber: Hasil uji korelasi sampel berpasangan, diolah menggunakan SPSS 19, (2016)

Tabel 4 memperlihatkan hasil uji korelasi untuk masing-masing komoditas. Dari nilai korelasi dapat dijelaskan hubungan yang kuat atau lemah dan hubungan positif atau negatif pada perubahan nilai sebelum dan sesudah masing-masing komoditas akibat implementasi tarif $0 \%$ ACFTA. Jika nilai signifikan (probabilitas) korelasi $<0.05$ pada tingkat signifikan $5 \%$ dan nilai korelasi > 0.5 menandakan bahwa hubungan tersebut kuat dan positif, yang bermakna korelasi perubahan (peningkatan) nilai ekspor komoditas tersebut terhadap implementasi tarif 0\% ACFTA benar-benar berhubungan secara nyata dan hubungan tersebut adalah positif.

Berdasarkan hasil yang diperlihatkan pada Tabel 4 yakni untuk keseluruhan komoditas pertanian diatas memiliki nilai korelasi $>0,5$ serta signifikan korelasi $<0,05$, hal ini bermakna bahwa perubahan (peningkatan) nilai ekspor ke 8 komoditas pertanian Indonesia ke Tiongkok adalah sangat erat kaitannya dengan implementasi tarif 0\% ACFTA serta benar-benar berhubungan nyata dan positif. 
Tabel 5. Hasil Uji Beda Sampel Berpasangan

\begin{tabular}{|c|c|c|c|c|c|c|c|c|}
\hline \multirow{3}{*}{$\begin{array}{l}\text { Sebelum- } \\
\text { Sesudah }\end{array}$} & \multicolumn{5}{|c|}{ Pair of Difference } & \multirow[t]{3}{*}{$\mathrm{T}$} & \multirow{3}{*}{$\begin{array}{l}\mathrm{d} \\
\mathrm{f}\end{array}$} & \multirow{3}{*}{$\begin{array}{l}\text { Sig. } \\
(2 \text { Tail } \\
\quad e)\end{array}$} \\
\hline & \multirow[t]{2}{*}{$\begin{array}{l}\text { Selisih } \\
\text { Mean }\end{array}$} & \multirow[t]{2}{*}{$\begin{array}{c}\text { Std. } \\
\text { Deviasi }\end{array}$} & \multirow[t]{2}{*}{$\begin{array}{l}\text { Std. } \\
\text { Error } \\
\text { Mean }\end{array}$} & \multicolumn{2}{|c|}{$\begin{array}{c}\text { 95\% Confidence } \\
\text { Interval the } \\
\text { Difference }\end{array}$} & & & \\
\hline & & & & Lower & Upper & & & \\
\hline $\begin{array}{l}\text { Minyak dan } \\
\text { Lemak } \\
\text { Hewani/Nabat } \\
\text { i }\end{array}$ & 1277,4 & 483,8233 & 216,3724 & $\begin{array}{c}676,733 \\
9\end{array}$ & $\begin{array}{c}1878,226 \\
0\end{array}$ & 5,904 & 4 & 0,004 \\
\hline $\begin{array}{l}\text { Karet dan } \\
\text { Produk dari } \\
\text { Karet }\end{array}$ & 1277,4 & 480,3853 & 214,8348 & $\begin{array}{c}681,002 \\
8\end{array}$ & $\begin{array}{c}1873,957 \\
1\end{array}$ & 5,946 & 4 & 0,004 \\
\hline $\begin{array}{l}\text { Kayu dan } \\
\text { Produk Kayu }\end{array}$ & 314,62 & 99,694 & 44,5847 & $\begin{array}{c}190,832 \\
9\end{array}$ & 438,4070 & 7,057 & 4 & 0,002 \\
\hline $\begin{array}{l}\text { Ikan, Udang } \\
\text { dan Makanan } \\
\text { Laut lainnya }\end{array}$ & 134 & 44,2277 & 19,7792 & 79,0839 & 188,9160 & 6,775 & 4 & 0,002 \\
\hline Kakao/Coklat & 52,6200 & 12,3732 & 5,5335 & 37,2566 & 67,9834 & 9,509 & 4 & 0,001 \\
\hline $\begin{array}{l}\text { Kopi, Teh dan } \\
\text { Rempah }\end{array}$ & 27,7600 & 13,7604 & 6,1538 & 10,6742 & 44,8458 & 4,511 & 4 & 0,011 \\
\hline $\begin{array}{l}\text { Sayuran dan } \\
\text { Buah-Buahan }\end{array}$ & 8,8800 & 1,1278 & 0,5043 & 7,4796 & 10,2803 & 17,606 & 4 & 0,001 \\
\hline $\begin{array}{l}\text { Gula dan } \\
\text { Kembang } \\
\text { Gula }\end{array}$ & 2,9800 & 1,3899 & 0,6216 & 1,2541 & 4,7058 & 4,794 & 4 & 0,009 \\
\hline
\end{tabular}

Sumber: Hasil uji paired t test, diolah menggunakan SPSS 19, (2016)

Tabel 5 memperlihatkan hasil uji beda sampel berpasangan. Dimana nilai mean masingmasing komoditas yang mencerminkan besaran nilai dari selisih mean sesudah - mean sebelum dari masing-masing komoditas. Standar Deviation menunjukkan dispersi rata-rata antar nilai ekspor sebelum dan sesudah implementasi ACFTA. Standart Error Mean 
(menunjukkan indeks variabilitas), batas atas dan batas bawah (Lower dan Upper), $\mathrm{t}$ hitung, derajat kebebasan (degree of freedom) 4, serta nilai signifikan (probabilitas).

Berdasarkan hasil uji beda sampel berpasangan yang diperlihatkan pada tabel 5 diatas dapat diketahui bahwa selisih nilai rata-rata dari keseluruhan komoditas tersebut adalah bertanda positif, yakni terjadinya peningkatan nilai ekspor setelah adanya implementasi tarif $0 \%$ ACFTA. dengan rata-rata nilai signiikannya $<0,05$, sehingga dapat disimpulkan adanya perbedaan yang signifikan, serta $t$ hitung $>t$ tabel $(\alpha / 2) 2,761$ pada derajat kebebasan $4(n-1)$. Maka hal ini bermakna terdapat peningkatan nilai ekspor lemak dan minyak hewani/nabati Indonesia ke Tiongkok pada periode sesudah implementasi tarif 0\% ACFTA. Dengan kata lain ACFTA berdampak positif terhadap nilai ekspor 8 komoditas pertanian Indonesia ke Tiongkok.

\section{KESIMPULAN DAN SARAN}

Berdasarkan hasil uji statistik sampel berpasangan menunjukkan bahwa nilai ekspor untuk keseluruhan jenis komoditas mengalami peningkatan yakni nilai ekspor minyak hewani/nabati sebelum US\$ 706,54 juta, sesudah sebesar US\$ 1984 juta; nilai ekspor karet dan produk karet sebelum US\$ 706,52 juta dan sesudah US\$ 1984 juta; nilai ekpor kayu dan produk kayu sebelum sebesar US\$206,02 juta dan sesudah sebesar US\$ 520,64 juta; nilai ekspor ikan, udang, dan makanan laut lainnya sebelum US\$ 44 juta dan sesudah sebesar US\$ 178 juta; nilai ekspor kakao sebelum US\$ 30,42 juta dan sesudah meningkat sebesar US\$ 83,04; nilai ekspor kopi, teh dan rempah sebelum US\$ 3,74 juta sesudah meningkat sebesar US\$ 31,50 juta; nilai ekspor sayuran dan buah-buahan sebelum sebesar US\$19,78 juta dan sesudah meningkat sebesar US\$28,66 juta; serta nilai ekspor gula dan kembang gula sebelum US\$ 1,18 juta dan sesudah meningkat sebesar US\$ 4,16 juta. Bermakna terdapat perbedaan signifikan kearah peningkatan terhadap nilai ekspor 8 komoditas pertanian setelah implementasi tarif 0\% ACFTA.

Berdasarkan hasil uji beda sampel berpasangan menunjukkan selisih nilai mean untuk 8 jenis komoditas pertanian yakni minyak dan lemak hewani/nabati sebesar US\$ 1227,5 juta; karet dan produk dari karet sebesar US\$ 1227,4 juta; kayu dan produk kayu sebesar US\$ 314,62 juta; ikan, udang, dan makanan laut lainnya sebesar US\$ 134 juta; kakao sebesar US\$ 52,62 juta; kopi, teh, dan rempah sebesar US\$27,76 juta; sayuran dan buah-buahan sebesar US\$ 8,88 juta; gula dan kembang gula sebesar US\$2,98 juta. Bermakna bahwa implementasi tarif 0\% ACFTA berdampak positif bagi ekspor 8 komoditas pertanian Indonesia ke Tiongkok dilihat dari nilai selisih mean yang bertanda positif.

Adapun saran yang dapat diberikan dari penelitian ini, yaitu bagi peneliti selanjutnya disarankan agar dapat memperluas pengamatan terhadap ACFTA dalam kaitan perdagangan luar negeri dengan negara-negara anggota ACFTA lainnya dalam jangka panjang. Serta Pemerintah dan pihak terkait sepatutnya optimis bahwa ACFTA sebagai bagian dari proses pembelajaran demi kemajuan bangsa dalam hal perdagangan luar negeri, yang dapat dijadikan sebagai batu loncatan bagi perdagangan luar negeri Indonesia di masa yang akan datang. Mengingat efek positif yang diterima oleh berbagai elemen dalam sebuah negara dari kegiatan ekspor itu sendiri, serta optimis bahwa ACFTA adalah sebagai sarana bagi Indonesia dalam memanfaatkan sumber daya serta hasil produksi yang dimiliki terhadap negara anggota ACFTA dalam hal ini adalah Tiongkok. 


\section{DAFTAR PUSTAKA}

Cashmore, Matthew (2003). Environmental Impact Assessment of Projects In The People's Republic of China: New Law, Old Problems. Environmental Impact Assessment, edisi 23 (5), 543-579, DOI: 10.1016/S0195-9255(03)00071-4

Direktorat Jenderal Kerjasama Perdagangan Internasional (2011). Perdagangan Indonesia dan ACFTA. Departemen Perdagangan Indonesia. Jakarta

Erawaty, A. F. Elly (2003) Globalisasi Ekonomi dan Perdagangan Bebas. PT Citra Aditya Bakti. Bandung.

International Trade Statistics Centre (2016). Bilateral Trade Between Indonesia and China (Total Comodities in Bilateral Trade). Diakses: 10 Maret, 2016 http://www.trademap.org/tradestat/Bilateral_TS.aspx

Ghozali, Imam (2009). Aplikasi Analisis Multivariat Dengan Program SPSS. Edisi 4, Badan Penerbit Universitas Dipenogoro Semarang.

IMF (2012). Dalam sigit setiawan. ASEAN-China FTA: The Impacts on the Export of Indonesia and China. Di unduh bulan Desember 2015 dari CEIC Database.

International Trade Statistics Centre (2016). Bilateral Trade Between Indonesia and China (Total Comodities in Bilateral Trade) . Diakses: 10 Maret, 2016 http://www.trademap.org/tradestat/Bilateral_TS.aspx

Kementerian Perdagangan Republik Indonesia (2010) Kajian Dampak Kesepakatan Perdagangan Bebas Terhadap Produk Manufaktur Indonesia. Jakarta

Santoso (2000). Statistik Parametrik. Cetakan Ketiga, PT Gramedia Pustaka Utama. Jakarta 